\title{
Early Cambrian granitoids of North Gondwana margin in the transition from a convergent setting to intra-continental rifting (Ossa-Morena Zone, SW Iberia)
}

\author{
T. Sánchez-García • M. F. Pereira • \\ F. Bellido - M. Chichorro - J. B. Silva • \\ P. Valverde-Vaquero $\cdot$ Ch. Pin · A. R. Solá
}

Received: 14 December 2012/ Accepted: 9 July 2013

(C) Springer-Verlag Berlin Heidelberg 2013

\begin{abstract}
Two distinct Cambrian magmatic pulses are recognized in the Ossa-Morena Zone (SW Iberia): an early rift-(ER) and a main rift-related event. This Cambrian magmatism is related to intra-continental rifting of North Gondwana that is thought to have culminated in the opening of the Rheic Ocean in Lower Ordovician times. New data of whole-rock geochemistry (19 samples), Sm$\mathrm{Nd}-\mathrm{Sr}$ isotopes (4 samples) and ID-TIMS U-Pb zircon geochronology (1 sample) of the Early Cambrian ER plutonic rocks of the Ossa-Morena Zone are presented in this contribution. The ER granitoids (Barreiros, Barquete, Calera, Salvatierra de los Barros and Tablada granitoid Massifs) are mostly peraluminous granites. The $\mathrm{Sm}-\mathrm{Nd}$ isotopic data show moderate negative $\varepsilon \mathrm{Ndt}$ values ranging
\end{abstract}

Electronic supplementary material The online version of this article (doi:10.1007/s00531-013-0939-8) contains supplementary material, which is available to authorized users.

T. Sánchez-García $(\bowtie) \cdot$ F. Bellido

IGME, C/Ríos Rosas, 23, 28003 Madrid, Spain

e-mail: t.sanchez@igme.es

F. Bellido

e-mail: f.bellido@igme.es

M. F. Pereira

IDL, Departamento Geociências, ECT, Univ. Évora,

Apt.94, 7001-554 Évora, Portugal

e-mail: mpereira@uevora.pt

M. Chichorro

CICEGe, FCT, Universidade Nova de Lisboa, Quinta da Torre,

2829-516 Caparica, Portugal

e-mail: ma.chichorro@fct.unl.pt

J. B. Silva

IDL, Departamento Geologia, FCUL, Universidade de Lisboa,

Lisboa, Portugal

e-mail: jbsilva@fc.ul.pt from -3.5 to +0.1 and TDM ages greatly in excess of emplacement ages. Most ER granitoids are crustal melts. However, a subset of samples shows a transitional anorogenic alkaline tendency, together with more primitive isotopic signatures, documenting the participation of lower crust or mantle-derived sources and suggesting a local transient advanced stage of rifting. The Barreiros granitoid is intrusive into the Ediacaran basement of the Ossa-Morena Zone (Série Negra succession) and has yielded a crystallization age of $524.7 \pm 0.8$ Ma consistent with other ages of ER magmatic pulse. This age: (1) constrains the age of the metamorphism developed in the Ediacaran backarc basins before the intrusion of granites and (2) defines the time of the transition from the Ediacaran convergent setting to the Lower Cambrian intra-continental rifting in North Gondwana.

P. Valverde-Vaquero

IGME, C/Calera, s/n, 28760 Tres Cantos, Spain

e-mail: p.valverde@igme.es

Ch. Pin

Département Géologie, CNRS, Univ. Blaise Pascal,

Rue Kessler, 63038 Clermont-Ferrand, France

e-mail: pin@opgc.univ-bpclermont.fr

A. R. Solá

LNEG, Apartado 7586- Alfragide, 2610-999 Amadora, Portugal e-mail: rita.sola@ineti.pt 